\title{
Procedure for the evaluation of transversal competences in lab practices: application to the course on heat transfer at the Polytechnic University of Valencia
}

\author{
Lina Montuori ${ }^{1}$, Carlos Vargas-Salgado $^{2}$, David Alfonso-Solar ${ }^{1}$, Paula Bastida \\ Molina $^{2}$ \\ ${ }^{1}$ Department of Applied Thermodynamics, Universitat Politecnica de Valencia, Spain, \\ ${ }^{2}$ Department of Electrical Engineering, Universitat Politecnica de Valencia, Spain.
}

\begin{abstract}
In this paper, a procedure for the systematic evaluation of lab practices based on the development of transversal competences is presented. This procedure includes the design and completion of specific rubrics (complemented with a personal interview at the end of the session) for each of the experiments carried out during the practice, considering both individual and group educational sides. So, aspects related to the student's behavior when working in-group (and the specific contribution of each student to the group), but also related to the individual performance, attitude, abilities and knowledge which the student should have previously acquired during the theoretical classes are considered.

A practical application of the developed method to the practices related to the course on Heat Transfer at the Polytechnic University of Valencia is presented, where some results are also summarized. In such application, the suitability of the proposed procedure is highlighted as a proper mean not just to evaluate, but also to help students developing both specific and transversal competences, which they will use during their whole career and professional life.
\end{abstract}

Keywords: Lab practices; rubric; heat transfer; transversal competences; evaluation. 


\section{Introduction}

According to the 2020 Plan, the Vice-rectorate for Studies, Quality and Accreditation of the Polytechnic University of Valencia, Spain (UPV) is supporting the Transversal Competences project since 2012. The result of this process led to the definition thirteen TCs, which are worked out with students in all the official degrees taught at the UPV, undergraduate and postgraduate courses (Bonet-Espinosa, Cabredo-Fagrés, Calvet-Sanz, de Andrés-Martínez, \& Soto-Pacheco, 2015). These competences represent a significant innovation, which is expected to provide students with an adequate job placement. However, the process for their integration is still under development, since, unlike the specific competences, the transversal ones do not yet appear in the final academic title, so that today there is not an appropriate methodology for their control and evaluation (Montuori, Alcázar-Ortega, Vargas-Salgado, \& Bastida-Molina, 2019). In this framework, the methodology proposed in this article may help professors to properly evaluate the skills developed by the students during the lab sessions, based on the aforementioned TCs.

A survey performed in 2018 to students enrolled in courses on Heat Transfer at UPV (Vilariño-Feltrer, et al., 2018) evidenced as lab practices are highly appreciated for the learning process of this matter. However, students also consider that the documentation provided to perform the practices should be further developed so as to improve the learning process associated to those practical sessions.

In line with these evidences, we propose in this article a kind of template that would facilitate the development of the practice, not just for students but also for professors who should evaluate the students' performance. Standard templates are necessary in order to properly organize the whole practice procedure since it is demonstrated as a well-defined protocol helps students to understand how they can expect to be evaluated, by the time it helps them to improve team work development (Delgado \& Fonseca-Mora, 2010). Such templates need to be complemented by rubrics, which necessarily include a sort of key factors that would allow evaluating the students' performance based on the development of transversal competences (TCs), such as Team Work, Problem Resolution or Critical Thinking.

The development of rubrics have been discussed by different authors in the past. Thus, a kind of rubrics for the evaluation of final projects and thesis of master can be found in (Martón, Gallardo, Villanueva, \& Ordóñez, 2018). On the other hand, rubrics for engineering classes and, more specifically, applied to Heat Transfer courses, have been studied by (Brown, Thiessen, Van Wie, Abdul, \& Adesope, 2012). In this article, we will integrate all these partial aspects in a whole process where the lab session process will be considered since the very beginning (before students come to class) to the conclusion once the session is finished. 


\section{Methodology}

The methodology here proposed for the evaluation of lab practices is based on a holistic three-phases procedure that we have designed as BDA: Before the performance of the practice; During the practice; and After the lab session. Therefore, this BDA procedure will allow the professor to evaluate the performance of students during the whole process of the practice.

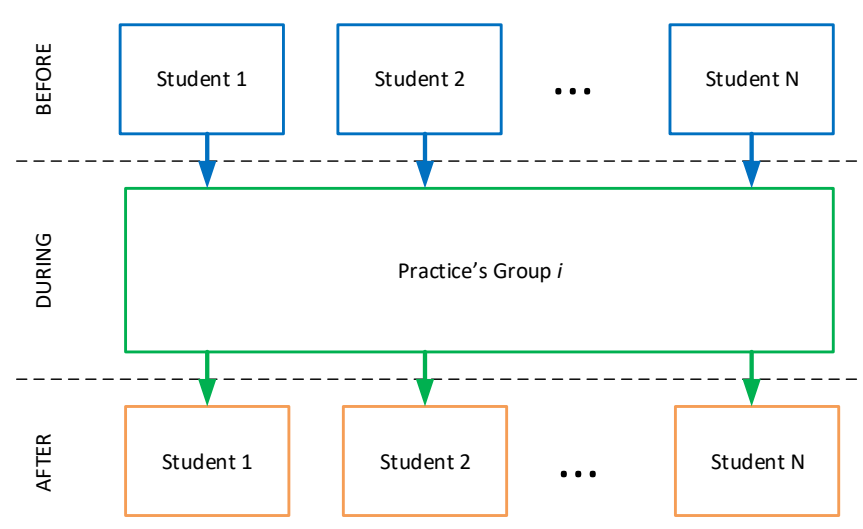

Figure 1. BDA Methodology for the evaluation of lab sessions.

The different phases considered to structure this designed BDA procedure, as depicted in Figure 1, are the following:

- $\quad$ Phase 1: BEFORE the lab session: Practice Preliminary

This first phase means a first approach to the session that students should have taken by reading the documentation provided in advance by the professor. It will be based on a quick questionnaire at the beginning of the lab session that students should answer individually, taking part in the final grade of the session. This activity is essential in order to guarantee that students have read the brochure of the practice before coming to class, so that they are aware about what they will do and what is expected from them.

A five short multiple-choice questionnaire will include some preliminary concepts related to the practice, such as:

- The aim of the practice

- The number and kind of experiments included in the practice

- Some theoretical aspect related to the preparation of the practice

- Some expected result that students should demonstrate during the lab session 
The questionnaire can be implemented in the well-known tool Kahoot, whose potential for evaluation purposes at University level has been widely discussed (Sempere Ferre, 2018). The estimated duration for this first phase is 10 minutes approximately.

- $\quad$ Phase 2: DURING the lab session: Practice Development

This phase will be the core of the practical session. During this phase, students will perform the different experiments included in the session. The procedure to be followed by students will be included on a standard template previously designed by the professor. In the template, students will write down the measurements they take during the session. Then, based on such measurements, some calculations will be required in order to demonstrate or validate some concepts previously studied in the theoretical classes. If the professor considers that some ancillary sheet is necessary (for example, when using some application or spreadsheet available at the lab), it will be also indicated in the template. The template will finish with a section of conclusions, where students should write the main results obtained during the session.

Practices will take place in groups, so that the evaluation of this part will be ingroup. It means that all the students in the same group will obtained the same grade in this part. However, the professor may take notes regarding the performance of each student during the practice, which will be incorporated and sharpened in during the Phase 3.

- $\quad$ Phase 3: AFTER the lab session: Practice Conclusion

After the completion of the different experiments of the practice, this last part of the evaluation process will consist of a personal interview between the professor and each student. Therefore, the grading of this part will be individual. Interviews will be short (1-2 minutes per student), so that no much additional time is required for the evaluator. In this last phase, students should explain the procedure followed in some of the experiments, which his/her contribution was or what the justification is for some of the obtained results.

\section{Rubric design and application to the labs on Heat Transfer}

The application of the methodology presented in the previous section is necessarily linked to the design of rubrics for the proper evaluation of the TCs related to each practice. As an example of this, Figure 2 shows the rubric designed for the lab \#3 of the course on Heat Transfer, which belongs to the Degree on Energy Engineering taught at the Polytechnic University of Valencia. As shown in the figure, the rubric is applicable for one group 
composed of five students as maximum, so that one individual rubric would be necessary for each lab group.

\begin{tabular}{|c|c|c|c|c|c|}
\hline Course: & Heat Transfer & \multicolumn{1}{|c|}{ e-mail } \\
& Practice \#3 & Student 1 & & & \\
\hline Practice name: & & Student 2 & & & \\
\hline Date: & $15: 00$ & Student 3 & & & \\
\hline Starting time: & 3 hours & Student 4 & & & \\
\hline Duration: & Student 5 & & & \\
\hline
\end{tabular}

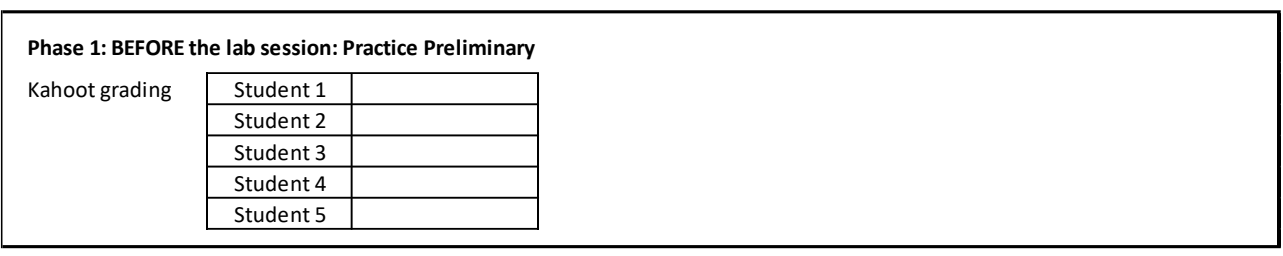

\begin{tabular}{|c|c|c|c|c|c|}
\hline \multicolumn{2}{|c|}{ Phase 2: DURING the lab session: Practice Development } & \multirow{2}{*}{$\begin{array}{c}\text { Measurements } \\
\text { accuracy }\end{array}$} & & & \\
\hline Experiment 1. & Heat exchangers characterization & & $\begin{array}{c}\text { Calculations } \\
\text { accuracy }\end{array}$ & $\begin{array}{c}\text { expression and } \\
\text { clarity }\end{array}$ & $\begin{array}{c}\text { Conclusions } \\
\text { quality (criticism) }\end{array}$ \\
\hline Experiment 2. & Verification of the Stefan-Boltzmann law & & & & \\
\hline Experiment 3. & Emissivity of different surfaces evaluation & & & & \\
\hline Experiment 4. & Flat solar collector analysis & & & & \\
\hline
\end{tabular}

\section{Phase 3: AFTER the lab session: Practice Conclusion}

\begin{tabular}{|l|c|c|}
\cline { 2 - 3 } \multicolumn{1}{c|}{} & $\begin{array}{c}\text { Individual } \\
\text { performance }\end{array}$ & $\begin{array}{c}\text { Role adopted within } \\
\text { the group }(A / P)\end{array}$ \\
\hline Student 1 & & \\
\hline Student 2 & & \\
\hline Student 3 & & \\
\hline Student 4 & & \\
\hline Student 5 & & \\
\hline
\end{tabular}

\begin{tabular}{|c|c|c|c|}
\hline $\begin{array}{c}\text { Question } \\
\text { Experiment 1 }\end{array}$ & $\begin{array}{c}\text { Question } \\
\text { Experiment 2 }\end{array}$ & $\begin{array}{c}\text { Question } \\
\text { Experiment 3 }\end{array}$ & $\begin{array}{c}\text { Question } \\
\text { Experiment 4 }\end{array}$ \\
\hline & & & \\
\hline & & & \\
\hline & & & \\
\hline & & & \\
\hline & & & \\
\hline
\end{tabular}

Figure 2. Example of Rubric for the evaluation of the lab \#3 on Heat Transfer.

This rubric allows the evaluation of the following Transversal Competences: Application and Practical Thinking; Teamwork and Leadership; Critical Thinking; Effective Communication; and Planning and Time Management. This evaluation will be done taking into account the grade obtained by the student in the different fields included in the rubric, as it will be indicated below.

In the Phase 1 section, the grade obtained by each student in the Kahoot questionnaire will be written down. This grade will take a numeric value, from 0 to 10 , directly provided by the Kahoot App.

In the Phase 2 section, four different criteria will be assessed: the accuracy of the measurements obtained by the students during the practice; the accuracy of the calculations 
performed, based on the obtained measurements, in order to determine the values requested for each experiment; the written expression and clarity in the elaboration of the report; and finally, the criticism and quality of the conclusions extracted during the development of the practice. These four factors will be evaluated by the professor for each experiment, according to the numeric scale proposed in (Montuori, Alcázar-Ortega, Vargas-Salgado, \& Bastida-Molina, 2019), based on the grading used in the Project of Transversal Competences of UPV (Bonet-Espinosa, Cabredo-Fagrés, Calvet-Sanz, de Andrés-Martínez, \& Soto-Pacheco, 2015):

Table 1. Numerical scale assigned to the level of development

\begin{tabular}{lr}
\hline $\begin{array}{l}\text { Level of } \\
\text { development }\end{array}$ & Numeric value \\
\hline A-Excellent & 10 \\
B-Good & 8 \\
C-Improvable & 6 \\
D-Not acceptable & 4 \\
\hline
\end{tabular}

While in Phase 2 the assessment is in-group based, in the Phase 3 section each student is individually evaluated. The first two columns refer to the aptitude of each student during the practice, so that this part will be completed according to the notes taken by the professor during the session, according to the behavior of each student within the group. In the first column, the professor will indicate the individual performance of the student, based on the grading scale indicated in Table 1, while in the second column, the professor will indicate whether the student had and active $(\mathrm{A})$ or passive $(\mathrm{P})$ behavior during the session.

Finally, the last four columns correspond to specific questions that each student should answer to the professor related to each of the practices developed during the session. Also in this part, Table 1 will be used for grading purposes.

Once the rubric has been completed, the TCs grading could be done according to the following expression:

$$
\text { Grade }^{C T_{k}}=\sum_{i=1}^{N} R B_{i} \cdot W F_{i}
$$

Where Grade ${ }^{C T k}$ is the grade obtained for each $k$ Transversal Competence; $R B_{i}$ is the grade obtained by the student in each factor of the rubric (from 0 to 10); and $W F_{i}$ is the weight assigned to each $R B_{i}$ factor, depending on the $k$ TC that is being evaluated. As an example, 
Table 2 shows the values for these coefficients applied to the Transversal Competences worked out during the Practice \#3 of the Course on Heat Transfer discussed in this section:

Table 2. Assignation of values for weighting factors. Example of application

\begin{tabular}{|c|r|r|r|r|r|}
\cline { 2 - 6 } \multicolumn{1}{c|}{} & $\begin{array}{c}\text { Application } \\
\text { and Practical } \\
\text { Thinking }\end{array}$ & $\begin{array}{c}\text { Teamwork } \\
\text { and } \\
\text { Leadership }\end{array}$ & $\begin{array}{c}\text { Critical } \\
\text { Thinking }\end{array}$ & $\begin{array}{c}\text { Effective } \\
\text { Communication }\end{array}$ & $\begin{array}{c}\text { Planning } \\
\text { and Time } \\
\text { Management }\end{array}$ \\
\hline $\begin{array}{c}\text { Measurements } \\
\text { accuracy }\end{array}$ & $20 \%$ & $0 \%$ & $10 \%$ & $0 \%$ & $10 \%$ \\
\hline $\begin{array}{c}\text { Calculations } \\
\text { accuracy }\end{array}$ & $30 \%$ & $10 \%$ & $10 \%$ & $0 \%$ & $10 \%$ \\
\hline $\begin{array}{c}\text { Written } \\
\text { expression and } \\
\text { clarity }\end{array}$ & $5 \%$ & $10 \%$ & $10 \%$ & $20 \%$ & $0 \%$ \\
\hline $\begin{array}{c}\text { Conclusions } \\
\text { quality } \\
\text { (criticism) }\end{array}$ & $10 \%$ & $10 \%$ & $40 \%$ & $20 \%$ & $10 \%$ \\
\hline $\begin{array}{c}\text { Individual } \\
\text { performance }\end{array}$ & $10 \%$ & $20 \%$ & $5 \%$ & $0 \%$ & $30 \%$ \\
\hline $\begin{array}{c}\text { Role adopted } \\
\text { within the } \\
\text { group }\end{array}$ & $0 \%$ & $20 \%$ & $15 \%$ & $0 \%$ & $0 \%$ \\
\hline $\begin{array}{c}\text { Questions } \\
\text { about } \\
\text { experiments } \\
\text { (avg) }\end{array}$ & $5 \%$ & $0 \%$ & $0 \%$ & $0 \%$ \\
\hline
\end{tabular}

\section{Conclusions}

Lab practices are more and more used nowadays for further developing a kind of Transversal Competences of students that they will use during their whole professional life. However, the evaluation of the level of development of such competences is a difficult task, so that professors need support to do it as objectively as possible. In line with this aim, this paper proposes a methodology for the systematic evaluation of lab practices based on Transversal Competences. This method provides also students with templates to be used during the practice. On the other side, profesors are provided with a sort of rubrics based on which such Transversal Competences could be assessed in a stardad way. This methodology is appropriate for groups of no more than 20 students (3-5 groups per session), that is the usual size for the lab sessions performed at the UPV, where this methodology is being now tested. 


\section{References}

Bonet-Espinosa, P., Cabredo-Fagrés, M., Calvet-Sanz, S., de Andrés-Martínez, D., \& SotoPacheco, P. (2015). Proyecto Competencias Transversales UPV. Valencia, Spain: Universitat Politècnica de València.

Brown, R., Thiessen, D. B., Van Wie, B. J., Abdul, B., \& Adesope, O. O. (2012). Development of a rubric based on Flink's Cognitive Dimensions in a Fluid Mechanics and Heat Transfer Class with potential applications in a variety of engineering classes. American Society for Engineering Education, 25.441.125.441.21.

Delgado, M. A., \& Fonseca-Mora, M. C. (2010). The use of co-operative work and rubrics to develop competences. Education for Chemical Engineers, 5, 33-39.

Martón, I., Gallardo, S., Villanueva, J. F., \& Ordóñez, J. (2018). Diseño de rúbricas para la evaluación de competencias transversales. Aplicación a trabajos Fin de Grado en ingeniería. IN-RED 2018, 19-20 July. Valencia, Spain: Universitat Politècnica de València.

Montuori, L., Alcázar-Ortega, M., Vargas-Salgado, C., \& Bastida-Molina, P. (2019). Metodología para formentar el aprendizaje activo de competencias específicas y transversales a través del soporte de sortwares ERPs educativos. IN-RED 2019. Valencia, 11-12 July 2019: UPV.

Sempere Ferre, F. (2018). Kahoot como herramienta de autoevaluación en la universidad. Congreso In-Red 2018 (págs. 250-255). Valencia (Spain), 19-20 July 2018: UPV.

Solari-Montenegri, G. C., Rivera-Iratchet, M. E., \& Abarca-Castillo, M. M. (2016). Rúbricas para la evaluación de la práctica profesional, el internado y el examen de titulación para la carrera de cinesiología según competencias generales y específicas, perfil de egreso y proyecto educativo institucional de la Universidad de Antofagasta. Fundación Educación Médica FEM, 19(5), 247-257.

Vilariño-Feltrer, G., Campillo-Fernández, A. J., Montagud, C., Navarro-Peris, E., PayáHerrero, J., \& Sarabia-Escrivá, E. (2018). Seguimiento del proceso de enseñanzaaprendizaje en la asignatura de transmisión de calor impartida en la Universitat Politècnica de València. INNODOCT 2018, 14-16 November. Valencia, Spain: Universitat Politècnica de València. 